\title{
Sero-epidemiological Study of Equine Piroplasmosis in Horses of South Gujarat (India)
}

\author{
Suresh Mavadiya ${ }^{1 *}$, Ramesh Patel ${ }^{2}$, Sudhir Mehta ${ }^{1}$, Jignesh Vala ${ }^{3}$, Saurabh Parmar ${ }^{3}$, \\ Irshad Kalyani ${ }^{4}$, Dhruv Desai ${ }^{4}$ and Jayesh Solanki ${ }^{5}$ \\ ${ }^{1}$ Department of Veterinary Medicine, Veterinary College, NAU, Navsari, Gujarat, INDIA \\ ${ }^{2}$ Department Veterinary Clinical Complex, Veterinary College, SDAU, Sardarkrushinagar, Gujarat, INDIA \\ ${ }^{3}$ Department of Veterinary Clinical Complex, Veterinary College, NAU, Navsari, Gujarat, INDIA \\ ${ }^{4}$ Department of Veterinary Microbiology, Veterinary College, NAU, Navsari, Gujarat, INDIA \\ ${ }^{5}$ Department of Veterinary Parasitology, Veterinary College, NAU, Navsari, Gujarat, INDIA \\ *Corresponding author: S. Mavadiya; E-mail:dr_svmavadiya@yahoo.co.in
}

\begin{abstract}
Equine piroplasmosis is considered a notifiable disease of worldwide significance and endemic in many countries of the world. This study was designed for the sero-detection of equine piroplasm and to investigate the associated risk factors of EP. A total 295 horse's serum samples were screened for $T$. equi and B. caballi infection by cELISA and result of the study indicated that $62.71 \%$ of horses having presence of antibodies by cELISA. Sero-prevalence of piroplasmosis in horses was found significantly $(\mathrm{P}<001)$ associated with different breeds of horses whereas non-significant difference was observed between age and sex of the horse. Highly significant $(\mathrm{P}<0.01)$ difference was observed in horses rear in pacca house and tick control adopted by owner for prevention of EP as compared to horses rear in kachcha house and ticks control not adopted by horse owner whereas significant $(\mathrm{P}<0.05)$ difference noticed in presence of tick infestations and absence of tick infestations on body of horses. Moreover, there was no any significance differences observed in presence of equine piroplasmosis from organized farm and unorganized farm, horses kept with other animal species and horses kept without other animals.
\end{abstract}

\section{HIGHLIGHTS}

(0 Pacca house and tick control strategies may reduce the incidence of piroplasmosis in horses.

(- Age, sex and breed have no relationship with occurrence of equine piroplasmosis.

Keywords: Horse, Theileria equi, Babesia caballi, cELISA

Equine piroplasmosis (EP) is a tick-borne disease caused by Babesia caballi and Theileria equi that affects horses, mules, donkeys and zebras. Both parasites are transmitted by ticks of genera Dermacentor, Rhipicehalus and Hyalomma. The disease is globally distributed and causes subclinical, clinical infections, and death. Till now, there are no valid reports of presence of $B$. caballi in most of the studies on equine piroplasmosis from India concentrate only on T. equi (Sumbria et al., 2016). The disease is reported from many parts of India (Sanjeev et al. 2020). The equine piroplasmosis in horses has been reported from other area of Gujarat state. (Dodiya et al., 2016, Vidhyalakshmi et al., 2018 and Bharai et al., 2020).

In 2004, the OIE approved the competitive Enzyme Linked Immunosorbent Assay (cELISA) for detection of antibodies against $T$. equi and $B$. caballi, and as a specified test for global horse activity (OIE, 2014). There is no previous serological study focusing on the occurrence of

How to cite this article: Mavadiya, S., Patel, R., Mehta, S., Vala, J., Parmar S., Kalyani, I., Desai, D. and Solanki, J. (2021). Sero-epidemiological study of equine piroplasmosis in horses of South Gujarat (India). J. Anim. Res., 11(1): 105-109.

Source of Support: None; Conflict of Interest: None (क) 8 
T. equi and B. caballi infection in horses of south Gujarat, India. Therefore, the prime objective of this research was to identify the presence of $T$. equi and $B$. caballi antibodies in the serum of horses with cELISA.

\section{MATERIALS AND METHODS}

\section{Collection and preservation of samples}

Total 295 blood samples from the horses were collected for diagnosis of equine piroplasmosis through cELISA test. The blood was collected from jugular vein of horses into a serum clot activators. The blood was centrifugated at $3000-$ $3500 \mathrm{rpm}$ for 15-30 minutes. The serum was separated and stored at $-20^{\circ} \mathrm{C}$ until further use for performing cELISA.

\section{Serological detection of $T$. equi and $B$. caballi antibodies}

The stored serum samples were assessed for the presence of antibodies to T. equi and B. caballi using a commercial cELISA test kit (VMRD, Inc., Pullman, USA) methods following the manufacturer's instructions. The optical density (OD) values of the controls and samples were measured at $630 \mathrm{~nm}$ wave length using an automatic microplate reader (Cyberlab, R01, USA) and the percentage of inhibition (\%) was calculated as follows: I $(\%)=100$ - $($ sample OD $\times 100) /($ mean OD of three negative controls). Serum samples with $\geq 40 \%$ inhibition were considered positive and samples with $<40 \%$ inhibition were considered negative as recommended by the manufacturer guidelines.

\section{STATISTICAL ANALYSIS}

The Chi-square test and R-software were used to differentiate the prevalence of equine piroplasmosis between various epidemiological factors. All candidate variables were kept in the model with significant attributes at $\mathrm{P}<0.05$.

\section{RESULTS AND DISCUSSION}

\section{Prevalence of equine piroplasmosis among horses}

Overall prevalence of piroplasmosis by cELISA is presented in table 1. In our study, the overall infection rate of EP was $62.71 \%(185 / 295)$ amongst them $61.69 \%$ (182) of T. equi infection whereas $1.02 \%$ (03) of horses found positive for $B$. caballi through cELISA. The low prevalence of piroplasmosis from Gujarat state has been reported as $16.67 \%$ by Khurana et al. (2014), and $11.52 \%$ by Vidhyalakshmi et al. (2018). Similar studies conducted in other parts of country where they observed that seroprevalence of $T$. equi in horses was $32.65 \%$ (Kumar et al., 2013), 24.66\% (Khurana et al., 2014), 49.66\% (Bhojani, 2016). The reason for higher prevalence of $T$. equi in this study might be the antibodies against $T$. equi are usually remains life-long whereas antibodies against B. caballi generally remain for 4-5 years. (Rüegg et al., 2008).

\section{Breed wise sero-prevalence of piroplasmosis}

Breed wise distribution of piroplasmosis by cELISA is presented in table 1. Sero-prevalence of piroplasmosis infection in this study was found significantly $(\mathrm{P}<001)$ associated with different breeds of horses. Non-significant difference of equine piroplasmosis according to breed of horses has been reported by Dodiya et al. (2016) and Bharai et al. (2020) from Gujarat. These differences could be due to different management conditions and practices adopted by horse owner (Sevinc et al., 2008). Elisa et al. (2016) stated that native breed of horses and mixed breed ones showed 3 times and 3.16 times respectively more risk to be seropositive to $T$. equi by cELISA than foreign breed horses. Higher prevalence of equine piroplasmosis in non-descript breed of horse as observed in the present study may be due to the larger population in studied area than any other breed. Breed wise prevalence of infection might also be depended on immune status of animals and management practice followed by the owner.

\section{Age-wise sero prevalence of piroplasmosis}

Age wise distribution of piroplasmosis by cELISA is presented in table 1. The age-wise prevalence was found to be non significant. Our findings were contradictory to Bharai et al. (2020) who reported that in Gujarat state the age wise prevalence of equine piroplasmosis in horses were higher in adult horses $(68.29 \%)$ followed by yearlings (17.07\%) whereas Dodiya et al. (2016) carried out a retrospective survey and reported that the age wise incidence of equine piroplasmosis was higher 
in adult group (2-18 years) of horses compared to other aged groups from Saurashtra region of Gujarat. Bhojani (2016) carried out epidemiological survey for equine piroplasmosis in Rajasthan (India) and confirmed that seroprevalence of equine piroplasmosis was higher in 1-5 year age group followed by 6-10 years age group. However, other epidemiological studies reported that the age wise prevalence of equine piroplasmosis in horses were older than 5 years were more likely to be seropositive for $T$. equi by Turaki et al. (2014), 2 to 4 years horses by Bahrami et al. (2014), between 6 and 10 years of aged horse by Hussain et al. (2014). Moreover, Ebrahimi et al. (2018) also reported prevalence of $T$. equi was higher in older animals than young equines.

Table 1: Overall, Breed-wise, sex-wise and age-wise seropositivity of $T$. equi

\begin{tabular}{lll}
\hline Type of protozoa & $\begin{array}{l}\text { No. of horses } \\
\text { tested }\end{array}$ & cELISA positive \\
\hline $\begin{array}{l}\text { Theileria equi } \\
\text { Babesia caballi }\end{array}$ & 295 & $182(61.69 \%)$ \\
Overall & & $03(1.02 \%)$ \\
\hline Breed & & $185(62.71 \%)$ \\
\hline Non-descript breed & 131 & $102(83.20 \%)$ \\
Sindhi & 117 & $63(53.84 \%)$ \\
Marwari & 29 & $12(41.37 \%)$ \\
Kathiyawari & 18 & $08(44.44 \%)$ \\
P value & 0.38 & $1.54 \times 10^{-5}$ \\
Sex & & \\
Male & 126 & $77(61.11 \%)$ \\
Female & 169 & $108(63.90 \%)$ \\
P value & 1 & 0.71 \\
\hline Age & & \\
\hline Foal (0-12 Month) & 10 & $04(40.00 \%)$ \\
Yearling (1-2 yrs) & 107 & $76(71.03 \%)$ \\
Adult (2-18 yrs) & 167 & $99(59.28 \%)$ \\
Aged (Above 18 yrs) & 11 & $06(54.54 \%)$ \\
P-value & 0.91 & 0.08 \\
\hline
\end{tabular}

\section{Sex-wise sero-prevalence of piroplasmosis}

Sex wise distribution of piroplasmosis by cELISA is presented in table 1. Gender was a definite risk factor, with females showing more positivity $(63.90 \%)$ to equine piroplasmosis than males $(61.11 \%)$. However, the sex/ gender wise prevalence was statistically non-significant. Similarly, Salib et al. (2013) and Turaki et al. (2014) reported a higher sero-positivity in stallions/male as compared mares which could be due to the different level of care, grooming and attention these animals were getting according to their importance for owners. However, mare is more prone to EP than stallion has been reported by Javed et al. (2014), Dodiya et al. (2016), Ebrahimi et al. (2018), Zeynel and Bekir (2019) and Bharai et al. (2020). Moreover, Bahrami et al. (2014) reported that both male and female horses have the same susceptibility of infection. The numerically higher sero-positivity found in females as compared to males in our study could be due to the large proportion of female equines enrolled for sampling as compared to males.

\section{Other risk factors associated with sero-prevalence of piroplasmosis}

The risk factor associated data with equine piroplasmosis are presented in table 2 .

Table 2: Risk factor related to positive for piroplasmosis by cELISA

\begin{tabular}{|c|c|c|c|c|}
\hline $\begin{array}{l}\text { Sl. } \\
\text { No. }\end{array}$ & Risk Factors & $\begin{array}{l}\text { Total } \\
\text { samples } \\
(\mathrm{N}=\mathbf{2 9 5})\end{array}$ & $\begin{array}{l}\text { Positive \% } \\
(\mathrm{N}=185)\end{array}$ & P value \\
\hline 1 & Organized farm & 123 & $78(63.41 \%)$ & \multirow{2}{*}{0.83} \\
\hline 2 & Unorganized farm & 172 & $107(62.21 \%)$ & \\
\hline 3 & $\begin{array}{l}\text { Kept with other } \\
\text { animal species }\end{array}$ & 98 & $62(63.26 \%)$ & \multirow{2}{*}{0.89} \\
\hline 4 & $\begin{array}{l}\text { Kept without other } \\
\text { animals }\end{array}$ & 197 & $123(62.44 \%)$ & \\
\hline 5 & $\begin{array}{l}\text { Presence of tick } \\
\text { infestations }\end{array}$ & 43 & $33(76.74 \%)$ & \multirow{2}{*}{0.039} \\
\hline 6 & $\begin{array}{l}\text { Absence of tick } \\
\text { infestations }\end{array}$ & 252 & $152(60.32 \%)$ & \\
\hline 7 & Pacca house & 183 & $102(55.74 \%)$ & \multirow{2}{*}{0.0015} \\
\hline 8 & Kachha house & 112 & $83(74.11 \%)$ & \\
\hline 9 & $\begin{array}{l}\text { Tick control adopted } \\
\text { by owner }\end{array}$ & 178 & $89(50.00 \%)$ & \multirow{2}{*}{$<0.00001$} \\
\hline 10 & $\begin{array}{l}\text { Tick control not } \\
\text { adopted by owner }\end{array}$ & 117 & $96(82.21 \%)$ & \\
\hline
\end{tabular}

Highly significant $(\mathrm{P}<0.01)$ difference was observed in pacca house and tick control adopted by owner compared to kaccha house and tick control not adopted by owner 
Moreover, there was no any significance differences observed in organized farm and unorganized farm, kept with other animal species and kept without other animals. Similar studies have been conducted by Bhojani (2016) who reported comparable data of risk factors associated with $T$. equi infection. Other study suggested that chances of contracting the piroplasmosis more higher in tick infestation major and equines have greater interaction with each other or other domestic animals which favors the multiply of tick infestation (Elisa et al., 2016, Ebrahimi et al., 2018 and Ali et al, 2019).

\section{CONCLUSION}

Among the 295 horses, $62.71 \%$ of horses had presence of antibodies for T. equi and B. Caballi. The breeds, sex age, organized/unorganized farm, horses kept with other livestock have no relation in occurrence of the infection. Further, it was found that the horses which kept in kachcha houses and not adopted tick control were more prone to piroplasmosis.

\section{ACKNOWLEDGEMENTS}

This work was a part of Ph.D. thesis submitted to Navsari Agricultural University, Navsari, Gujarat. Authors would like to thanks College of Veterinary Science and A.H., Navsari Agricultural University, Navsari, Gujarat for providing funding to facilitate the research.

\section{REFERENCES}

Ali, S., Ijaz, M., Farooqi, S.H., Durrani, A.Z., Rashid, M.I., Ghaffar, A., Ali, A., Rehman A., Aslam, S., Khan, I., Masud, A. and Mehmood, K. 2019. Molecular characterisation of Theileria equi and risk factors associated with the occurrence of theileriosis in horses of Punjab (Pakistan). Equine Vet. Educ., pp.1-9. doi: 10.1111/eve.13161.

Aziz, K.J. and Al-barwary, L.T.O. 2019. Epidemiological study of Equine piroplasmosis (Theileria equi and Babesia caballi) by microscopic examination and competitive-ELISA in Erbil province North-Iraq. Iran J. Parasitol., 14(3): 404-412.

Bahrami, S., Ghadrdan, A.R., Mirabdollahi, S.M. and Fayed, M.R. 2014. Diagnosis of subclinical equine theileriosis in center of Iran using parasitological and molecular methods. Trop Biomed., 31(1): 110-117.

Bharai, M.J., Patel, J.S., Parmar, V.L., Patel, U.D. and Fefar, D.T. 2020. Prevalence of Equine Piroplasmosis in and
Around Junagadh in Horses. Indian J. Vet. Sci. Biotechnol., 15(3): 49-51.

Bhojani, R.J. 2016. Epidemiological and diagnostic studies on piroplasmosis in horses. M. V.Sc. (Vet.) Thesis. Rajasthan University of Veterinary and Animal Sciences, Bikaner.

Camacho, A.T., Guitian, F.J., Pallas, E., Gestal, J.J., Olmeda, A.S., Habela, M.A., Telford, S.R. and Spielman, A. 2005. Theileria equi and Babesia caballi infections in Horses in Galicia, Spain. Trop. Anim. Health Prod., 37: 293-302.

Dahiya, R., Salar, R.K., Mandal, K.D., Kumar, R., Tripathi, B.N., Pal, Y. and Kumar, S. 2018. Risk factor analysis associated with Theileria equi infected equines in semiarid and subhumid ecological enzootic zones of India. Vet. Parasitol. Region Stud. Rep., 12: 17-21.

Dodiya, P G., Patel, J.S., Vijay, L.P., Amit P., Murabiya, K.K., Vaghela, D.V. and Patel, P.B. 2016. Prevalance of equine piroplasmosis in and around saurshtra region in horses. Int. J. Environ. Sci. Technol., 5(3): 1488-1491.

Ebrahimi, M., Adinehbeigi, K., Hamidinejat, H. and Tabandeh, M.R. 2018. Molecular characterization of Theileria equi infection in horse populations belonging to West Azerbaijan, Iran: insights into the importance of Equine Merozoite Antigen (EMA)-1 in its diagnosis. Ann. Parasitol., 64(1): 2127.

Elisaa, B. D. P. L., Nardini R., Veneziano V. Iacoponi F., Cersini A., Autorino G. L., Buono F. and Scicluna M. T. 2016. Babesia caballi and Theileria equi infections in horses in Central-Southern Italy: Sero-molecular survey and associated risk factors. Ticks Tick Borne Dis., 7: 462-469

Hussain, M.H., Saqib, M., Raza, F.G., Muhammad, G., Asi, M.N., Mansoor, M.K., Saleem, M. and Jabbar, A. 2014. Seroprevalence of Babesia caballi and Theileria equi in five draught equine populated metropolises of Punjab, Pakistan. Vet. Parasitol., 202(3-4): 248-56.

Khurana, S.K., Singh, B.K., Yadav, S.C., Gulati, B.R., Malik, P., Kumar, R., Virmani, N., Kumar, S., Barua, S., Vaid, R.K., Manuja, A., Dedar, R. and Singha, H. 2014. Surveillance, monitoring and control of existing and emerging diseases of equines. National Research Centre on Equines (NRCE), Annual Report (2013-2014). Hisar-125 001, India, pp. 26.

Kumar, S., Kumar, R., Gupta, A.K., Yadav, S.C., Goyal, S.K., Sandip, K., Khurana, S. K. and Singh, R. K. 2013. Development pf EMA-2 recombinant antigen based ELISA for sero-prevalence studies of Theileria equi infection in Indian equine population. Vet. Parasitol., 198: 1-17.

OIE, 2014. Equine piroplasmosis. In: Manual of Diagnostic Tests and Vaccines for Terrestrial Animals. $6^{\text {th }}$ Edition. Paris, France, pp. 884-891. 
Rüegg, S.R., Heinzmann, D., Barbour A.D. and Torgerson, P.R. 2008. Estimation of the transmission dynamics of Theileria equi and Babesia caballi in horses. J. Parasitol., 135(5): 55565.

Salib, F.A., Youssef, R.R., Rizk, L.G. and Said, S.F. 2013. Epidemiology, diagnosis and therapy of Theileria equi infection in Giza, Egypt. Vet. World, 6(2): 76-82.

Sanjeev, K., Vikrant S., Daya S. and Anjali, D. 2020. Babesia (Theileria) equi genotype A among Indian equine population. Vet. Parasitol. Reg., 19: 100367.

Sevinc, F., Maden, M., Kumas, C., Sevinc, M. and Ekici, O.D. 2008. A comparative study on the prevalence of Theileria equi and Babesia caballi infections inhorse sub-populations in Turkey. Vet. Parasitol., 156: 173-177.

Sumbria, D., Singla, L.D. and Sharma, A. 2016. Theileria equi and Babesia caballi infection in equids in Punjab, India: a serological and molecular survey. Trop. Anim. Health Prod., 48: $45-52$.
Turaki, U.A., Kumsha, H.A., Biu, A.A. and Bokko, P.B. 2014. Prevalence of piroplasmosis amongst local horses in Northeastern Nigeria. J. Agric. Vet. Sci.., 7(12): 04-07.

Vidhyalakshmi, T.M., Sunant K.R., Bharat B.B. and Amit, K.K. 2018. Prevalence of Theileria equi among Horses Based on Parasitological and Universal Molecular Technique. Int. J. Curr. Microbiol. App. Sci., 7(10): 318-323.

Vieira, T.S.W.J., Vieira, R.F.C., Finger, M.A.P., Nascimento, D.A.G., Sicupira, P.M.L., Dutra, L.H., Deconto, I., BarrosFilho, I.R., Dornbuschc, P.T., Biondoc, A.W. and Vidotto, O. 2013. Seroepidemiological survey of Theileria equi and Babesia caballi in horses from a rural and from urbanareas of Paraná State, Southern Brazil. Ticks Tick Borne Dis., 4: 537-541.

Zeynel, A. and Bekir, O. 2019. Seroprevalance of Theileria equi and Babesia caballi in Horses of Mus Provice, Turkey. Alex. J. Vet. Sci., 60 (1): 22-29. 
